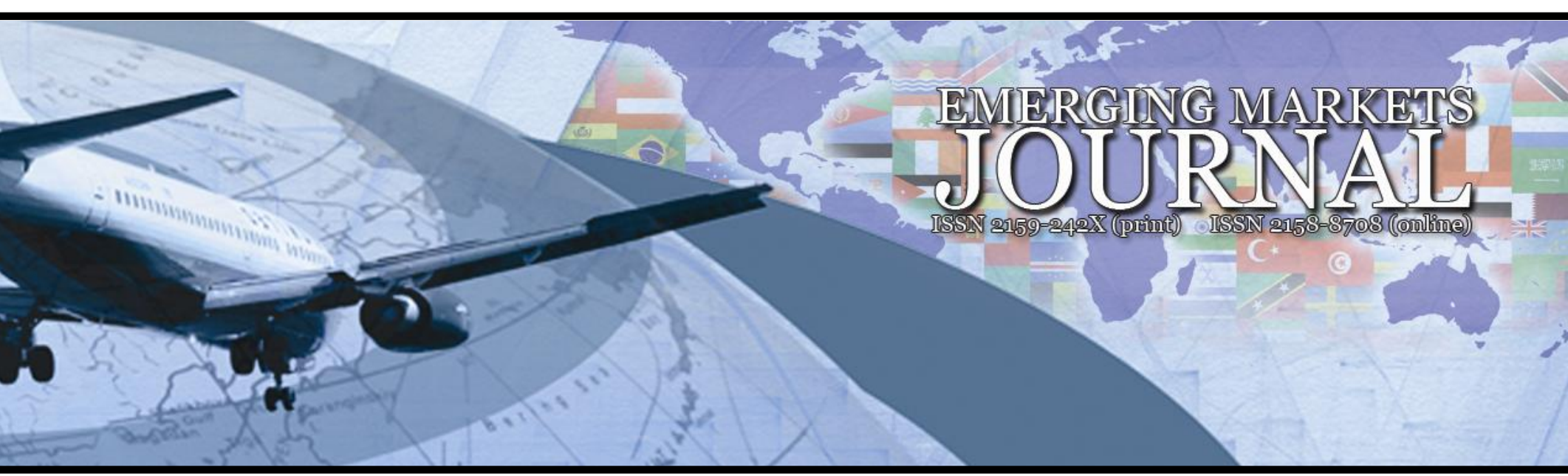

\title{
Fashion as a Marketing Tool and Its Communication Aspect in Developing Markets
}

\section{Dr. Fatma Engin Alpat}

Beykent University | e-mail: engin@ beykent.edu.tr,$\underline{\text { alpat35@gmail.com }}$

\section{Dr. Yusuf Ziya Aksu}

Aktin | e-mail: yaksu@aktin.com

Volume 3 No 3 (2014) ｜ＩSSN 2158-8708 (online) ｜ DOI 10.5195/emaj.2014.56 | http://emaj.pitt.edu |

\section{Abstract}

In this article the idenfication of a fashion product, its variability and the analyses of fashion as an industrial design will be discussed within the framework of fashion product marketing. The process of product creation is closely related to the economic, sociological and psychological factors considered, hence, sociologists and trend setters are working together because the concept of fashion product should be viewed as a determiner of status and power of a certain community. Each group within the community should be defined within a certain status and therefore each status corresponds to a relevant fashion concept. The survival of the fashion designers within the industrial sector could only be plausable if fashion is firstly analyzed conceptually and then applied separately to each group of the community.

Keywords: Fashion marketing, fashion business, fashion sociology, fashion and communication.

\section{(cc) $\mathrm{EY}$}

New articles in this journal are licensed under a Creative Commons Attribution 3.0 United States License.

\section{UILIS D-Solfe}

This journal is published by the University Library System of the University of Pittsburgh as part of its D-Scribe Digital Publishing Program, and is cosponsored by the University of Pittsburgh Press. 


\section{Fashion as a Marketing Tool and Its Communication Aspect in Developing Markets}

\author{
Dr. Fatma Engin Alpat \\ Dr. Yusuf Ziya Aksu
}

Globalism's repercussions on the textile industry and problems:

The condition of the Turkish textile industry and its future has long been an issue for textile exporters as well as the academics working on this field. The economic and social globalism and its formal repercussions on production have been forcing manufacturers and theorists to develop new theories and practices.

These efforts also include the repercussions of the international competition that will become liberalized with the GATT (General Agreement on Tariffs and Trade) agreements by the European Union Affairs and Foreign Relations Department on textile industry, as well as the precautions to be taken.

Turkish textile industry will certainly be hit by international competition, especially regarding price levels. Given the countries where wages and extra labor costs steer at lower levels than Turkey, both the consumers and the manufacturers will be affected. Faced with hardship already, manufacturers have been lowering their profit margins and disregarding cost of redemption and recession with an aim to exist in international markets.

The Turkish textile industry needs to develop new policies which will enable it to resist price competition, which will only become fiercer year after year. Rationalization of production, uncompromising application of quality management principles, opening to new markets, and shifting production to Eastern Turkey are measures which only provide a temporary advantage in price competition. They will not be enough to close the wage disparity between Turkey and countries that enter the market in the medium term. The Turkish textile industry will be facing hardship in this new situation.

\section{New Marketing Tools in Turkish Textile} Industry:

The Turkish textile industry's ability to develop new manufacturing and marketing strategies will determine if it can overcome the aforementioned hardships and make a fresh leap forward. It needs to find itself a new place in the global competition that escalates day by day. The problem consists of not only growing price competition but also a rise in supply. This is because developing countries that shift from national to international markets prefer the production and export of textile products. The foreign trade policies of developed countries which manufacture textile industry machinery also support these efforts. Capital is the main problem in developing countries. This is solved directly by lending from developed countries and indirectly by the resources of World Bank for textile industry investments. Thus, an emphasis on price and cost aspects in international competition and continuously asking for government subsidies would indicate an error of only seeing a single aspect of the problem. Precautions that are taken regarding only a single dimension can bring a short term solution, but will create new problems in mid and long terms while causing the country's resources to shift to inefficient fields.

Instead of thinking with only one dimension, one needs to make sure to consider the situation with all its dimensions and propose long term solutions.

\section{1) The fashion dimension of globalism:}

It is impossible to ignore the positive sides of globalism to Turkish textile industry along with the negative. One positive aspect is the increased tendency for fashion and brands that comes with globalism. Even though fashion was a socio-cultural phenomenon that existed before globalism and even shaped people on a national or even regional basis, it took a fast turn with globalism. It was transformed into a factor that deeply affects marketing strategies. From a sociological point of 
view, fashion is a phenomenon that deals with consumers' need to be different and to be perceived differently. The feelings of transformation and differentiation that exist within consumers' and users' egos manifest themselves an interest in fashionability. In pret-a-porter, conforming or not conforming to fashion is a character badge and highlight. Fashion enables individuals who act collectively in a psychosociological and cultural context, to form individual approaches. In other words, individuals belonging to a certain society get the opportunity to express their personality and go beyond the formal structures that society has formed. Thus, although defined as a abstract concept, it can also be observed as a concrete product with regard to fulfilling need. It is important to know the meaning and properties of the concept of fashion when marketing fashion products.

A fashionable product is special and has distinct properties. For instance, fashionable products get popular fast but fade away quickly as well. Every product exists within a series. Fashion does not only bring changes to the look of a certain series, but bring changes to many different series. Fashion is always a new product. Fashion is an abstract concept based on thinking, but also a solid product that fulfills physical and mental needs. Whereas technological progress is usually a slow process, fashion is as variable as society since it is influenced by public events, economy and social life. Thus, anybody who has an interest in fashion, artisans, stylists, manufacturers big or small face complex problems. These problems occur due to the deep necessity to recognize the consumer and the market as well as the concepts that determine fluctuations and shifts in the market. It is a reality that political, economic, societal (psychological and sociological) events continously influence fashion.

\section{1 - The Fashion Phenomenon}

"A fashion product lives through 4 stages: Market entrance, growth, maturity and decline. It is observed that consumers distinctly hesitate at the begining of fashion changes. "1 "Consumers want to follow fashion without taking any risks. Consumer anxiety needs to be appeased by offering that the novelty does not clash with already existing system of values and that it is acceptable. The concept of collective understanding allows a psycho-sociological snapshot to be taken of the cultural society made up from individuals. Basic or model personality can be defined as the total of the properties that are alleged to the individuals of a certain society. ${ }^{2}$ Materialistic culture in the act of consumption is merely a hidden element in collective understanding and basic personality.

"Aside from the observable parts of a product, consumers have mental designs that force them to see objects from a subjective point of view. Material culture defines the objective aspect of a thought or a group of values. Only Products become a societal indicator and carriers of a statement. If a new material is to enter the market and we want it to be a 'symbolic fashion' we need to recognize which points to consider as preparation before design.

Individuals do not react only based on their environments or those who are around them. Every individual has a dream share which exceeds his daily life. Fashion creations provide opportunities for these attitudes to symbolically actualize via clothing style."3 The community that the individual belongs to is created by the concious designs that he posesses regarding his own status. The community that the individual applies to stands opposite to the community that he belongs. The individual draws his ideal self within this community. The community that the individual applies to affects him in three ways:

\footnotetext{
${ }^{1}$ Moda Olgusu, Cem Hakko İstanbul 1980 p.2

${ }^{2}$ Arıkan, Moda, Kültür, Kimlik İstanbul, 1997, p.35

${ }^{3}$ Barthes Roland, 1990, p. 62.
} 
a) Affects his attitude and self-image by providing behavior and lifestyle models;

b) The influence of the community to be applied increases when their consumption includes products or brands that are based on showing off. Fashionable products provide the consumer with various opportunities in creating mental images. Renewal of fashion, increase in forms and development of new products incessantly recommend various standings.

The increasing success of industries that provide false opulence such as false jewelery, false leather, false entertainment and false luxury which satisfy the individual at least for the moment is based on the existence of communities to be applied.

Leading points that relate to the occurence of novelty in fashion:

The novelty needs to be subject to an experiment to be compared and analyzed against various forces and demands within the individual. The product to be perceived and the perceiver, exist in a process of temporary deconstruction and reconstruction within a certain structure. Finally, one ceases to see the novelty as "a thing" and identifies with it. Being involved in a new behaviour makes it easy for the individual's structure to change as well. It has been proven that fashion actualizes ongoing changes.

\section{2. - Relationships between Fashion-}

\section{Product- Marketing:}

It is especially important to define the word new by how it manifests itself rather than the techical meaning. Fashion is the slave of imagination and just like in nostalgy movement it is inspired by the past as well as the future.

"Another characteristic of fashion is that its future often cannot be guessed or controlled. Fashion is not based on mathematical equations, cannot be analyzed completely by science. Fashion is an industry that faces unique obligations due to the variable character of industry standards."4

It is a must to see the future in fashion industry and it is in a tight relationship with a modern understanding given this topic. For instance:

1) A fashion house can never develop through empricial means.

2) A fashion house has to renew fashion or create fashion following serious research.

3) It is necessary to know the markets and the reasons consumers change their taste in order to spread fashion products to the market.

It is necessary to always be current with new investments and costs due to shifts in fashion leading to shifts in manufacturing.

The price of a fashion product does not only depend on its cost. This fact does not change even when it is obvious that a certain profit margin is added on top of the cost. The selling price actually depends on the significance of the fashionable product, the apparent necessities and necessities that are yet to be realized, the supply and the quality provided by the competition. These factors also affect how strongly that fashion is established."

The price requested by a consumer depends on the quality desired of a certain product. Quality does not have an absolute meaning for fashionable products. It is necessary to define the concept of quality based on the use of the product. A useful product that is sought for its utility and a show-off product desired for its aesthetic value can both be said to have quality. However, there are a limited number of products that carry both of these properties.

\footnotetext{
${ }^{4}$ Barthes Roland 1990 p.63

${ }^{5}$ Hakko, Cem, Moda Olgusu, İstanbul 1990 p.47
} 
For a fashion to catch on, the appropriate timing should be determined so that the conditions before an after a novelty make it clear which benefits a novelty will bring. The introduction of the novelty should only be started once the benefits that will be brought by the novelty have become a necessity for the audience, and once the societal arrangements that will have been made that will make such benefits possible. Establishing the two way communication through which fashion is presented to the audience requires continuous feedback from the audience, so that the fashion is learned correctly. The adoption of the fashion by the audience should only be attempted after preparation using mass communication tools and live presentations. From a mass communication perspective, cinema is one of the fundamental phenomena of our time. It plays a fundamental role in the creation of contemporary legends. The legends that cinema creates, along with sports and fashion, occupies a more central place than religious beliefs, political ideologies or other value systems in many modern men and women's worlds. Interpersonal communication occurs when source and target units talk face to face. In mass communicaton, source and target units do not face each other. Newspapers, magazines, film, radio, televison, graphic advertisements constitute mass communicaton.

It is possible to reach a great number of targets given a large amount of time and place. Mass communication differs from interpersonal communication in terms of feedback loops, communication media and constraints of exposure. That is to say, there exists only broadcast and the number of people that can be reached is unlimited. It is more effective in the transfer of knowledge. Flow of information is achieved through visual, written or emotional means. In Turkey's societal transformation, mass communicaton plays an important role. Criticism of mass communcation in our time is limited to the audience not liking what is given to them. The culture that is produced is criticised according to the masses.

Fashion is defined by the common tastes and temporary ways of living and feeling observed in a certain society. Since it is people who prepare the status of fashion in mass communication, the abstract images given in mass communicaton tools, the transformation of the systems of communicaton between masses, social living, the general lifestyles of couples, the changes that arise in these interaction perform their jobs and enable a great cycle, transformation and circulation. Since fashion is by nature changing and ambivalent, advertising in turn should not be monotonous. Fashion always desires to be universal, it desires to see and to be seen, it is exhibitionistic. When presented in a medium that emphasizes novelty, fashion creates a great attraction in terms of the product's success. People who adopt a fashionable concept help not only the fashion's survival but also its propogation. Advertising also undergoes certain turbulences along with the fasihonable products. The changes in advertising itself are the first signs of a changing fashion rather than the cause of its evolution. Mass communication is a transformation that bends the rules of media and affects the way people communicate with each other.

\section{3 - Mass communication tools and}

\section{fashion:}

There is a three-way back and forth transmission between masses. Media and fashion benefit from psychology and Freud in regards to buying concepts. Fashion is the least stable art of telling oneself of our century's industries. It is for this reason that its marketing strategies are unique. Fashion is also the process of change for behaviours, presumptions and uses in a certain community activity towards what is suggested. Fashion is shot term and has visual translations. The basis for this fast evolution is the contagiousness of a way of thought or behaviour that acts as a model that makes itself adopted by force. Addiction and availability can lead to fast and complete change. Those who are 
open to pressure, direct information can also make an impact. Mass communication tools are the enablers of all of these psychological approaches. This requires professionality. Communication is vital for fashionable products. Fashion is also dominant on advertisements and brands.

Communication tools which enable fashion to spread (in order) are: Traditional ads, promotions, direct marketing, a respectable public relations chain, display and counter arrangements, expos and fashion shows. The effective percentages of such communication methods in relation to fashion is as follows: Ads and promotional stands on location: $45 \%$, ads via mass communication tools and media: $25 \%$, TV ads 12\%, media and other communication tools: $17 \%$. For the advertisements to be succesful, images which have an impulse of differentiation in a unique identity or ads which have an impact of getting closer or likening to a higher class are created.

Today, the great power of mass communication tools determine popular culture. A culture is created for the masses by experts via these means. According to Roland Barthes, presenting the people with happiness, luxury and welfare is a totaliatarian attitude. If people accept another way of thought, this attitude is not liked. The problem is not so much as that criticism is not made, but that it does not reach its target. Cultural life is dived into elite and non-elite categories. Also important is who rules the mass communication sources. These are in the hands of the private sector in the USA, and in government's hands in Russia. Turkey has taken Europe as an example in this matter.

\subsection{Semiotic language of fashion:}

To approach the matter in terms of fashion graphics and semiotics, semiotics can be deemed as the beginning of structuralism.

As in graphics, symbols are in the form of index (Marking) systems. An indicator has three meanings which are psychological, semantic and logical. Fashion system is a language and it has a referential function towards us. Relationship function establishes the communication function in the fashion system. Cloth is a top language. It is provided, seen, perceived and understood. This entire order has the same system with graphic arts; the philosophy and basis of interior architecture are on the same 'mode' with graphic arts.

Fashion system is a terminological and semiological system. We show its terminological aspect through graphic and spoken or written language. Social structure can be analyzed based upon fashion system and also mass communication methods suitable for the structure can be developed. A bilateral communication arises because semantic relationships vary socially and esthetically according to societies. A constant fashion discourse is a form belonging to fashion world, which means that the fashion has a unique, variable, indecisive, confused, inconsistent, attractive, alluring and effective world. History and fashion photography and all of them are included into the media system.

Fashion can expand insofar as economical aspects permit. It is a mistake to think that expensive materials will become fashion in periods where economical distress arises. Fashion (1) is characterized by materials and techniques unique to every period in human progress, and (2) creates its own extraordinary set of values and unique ways of thinking in all periods. Each successful period is founded on the successes of previous periods. These principles involve two common grounds of our era: (1) Adaptation of design processes with production processes, and (2) arrangement of production according to artistic findings regarding to esthetic values.

Even though production processes are changed, insights which are effective in self-refreshing art will have a function to create fashion, together with the integration of esthetic ideas existing in human nature with the artistic findings, while fashion will also have a function to create manufacturer and the innovation.

Creation is performed in two phases which are mental and physical. Mental creation presents fashion. Fashion concept is the transfer of mental embodiment to the material to be used. In this way, physical form appears. In addition to the function that physical form is required to have, 
there are also other factors as well as material and technology: 1) Human happiness, 2) Goal congruence, 3) Change, 4) Four dimensionality, 5) Functional sort order. The requirement to interpret design properly aims to satisfy and make human happy. Products which are the result of produced designs should be able to satisfy emotional requirements of human psychophysiologically. We are living in a world where social, political, economical and esthetic elements dominate. If we address them as a whole, changes and movements carried out within these elements determine, develop, make to expire and change fashion concept. As everything is evaluated according to human, and since human is a three dimensional entity, four dimensionality is the time affecting human. Also this is a human factor affecting social, cultural, technological, economical, esthetic, and physical concepts. Fashion is a process of change and it takes its form according to requirements of changing pleasures. Fashion becomes a concept by integration of esthetic and economical factors with the art. Although concept of fashion emerged due to economical conditions, it has been diversified by esthetic factors. Despite the fact that fashions of particular periods followed each other due to economical factors, fashion has been regenerating itself in due course. The aspect of fashion depending on economical factors is the evaluation of fabric, dye and material needs by reconsidering. For world textile manufacturers, current general and economical conditions are of first priority. The world determines and decides fashion one year earlier. After opportunities within the determined process are equalized with the social and economical status of people, it is offered by enriching with esthetic elements. In this way, it is provided to influence people by the concept of fashion.

People try to follow and catch the concept of fashion to some extent. Except the fashion, economical factors affect a textile product beginning from the start of design process up to the delivery of product to consumer. When interpreting, a design within the context of economical conditions should be kept away from all kinds of extremism and wastage. Today where it is aimed to produce the best with the lowest cost (the concept of 'best' is deemed as satisfying needs in the best way), the money spared by investors for fashion affects designer and creator substantially. Therefore, the fashion and all personal pleasures and choices necessarily depend on economical factors.

There is a communication between human and textile product. "Communication research methods" are among the widest context of social sciences.

Social sciences address this communication type, rules, laws and systems models in pragmatic reviews and assert by qualitative and quantitative researches. Communication types of human with other human beings and objects around have been addressed in terms of textile products. It has been found in the communication of an individual that there are thinking and acting, explanatoriness, responsibility, foresights, diversities, variation among individuals and characteristic or distinctive classifications, and all these elements affect the relationship of human with textile products. Because human is a quite complex entity with various aspects such as body, thought, feelings and faith. On the other hand, physical appearance and personality are the constant and significant factors of human showing continuity for the entire life. Inherited motives and desires of human, behaviors, the desire to maintain or change an identity, identity seek, roles turns textile product into a tool which will satisfy human ego instead of being just a need for such interactions.

Capturing and using this tool, and living within the concept of fashion are the source of psychological energy underlying human behaviors and engage as to pleasure principle. Individual expect all his/her demands to be performed immediately while individual may not be aware of the impacts of these impulses. 'The system of thought' transforms human into the individual of society.

It is seen that the terminology of fashion has been changed since the emergence of fashion. Fashion has some aspects associated with identity and character; it has an eccentric and conventional language. The fashion is like the elocution, clothes of others come to our attention. It is seen that people may conceal their actual faces by clothes and display a fake image and behavior pattern. In the business life, the phrase "first image is important" highlights the importance of a presentable appearance. Why people wear? The answer today is not similar with the one in first and middle ages anymore. The answer: Creating a character, 
distinguishing genders, defining an identity, and protecting our own interests. The concept of fashion prepares some roles for people, and also gives people the right of initiative. Individuals take real roles during their entire lives because human life is real.

We can say that there is both nothing and everything in fashion. A dancing dress states its own function. However, the function of a fashionable cloth is more complicated than the dancing dress. The rhetorical aspect of fashionable cloth is more than its other aspects. To say "Short skirts are in fashion this year" means that short skirt is the indicator of the fashion this year. Fashionable in terms of people and textile products relations is what is in fashion, of brand, mentioned about, written about and demonstrated; what not fashionable is what is not in fashion, not of brand, not mentioned about, not written about and not demonstrated. Fashion creates the consumer potentiality that trade requires. At the present time fashion creates a good shot point or a starting point for earning revenues and consumer crises.

Therefore it creates a feeling of living before in people. In decoration fashions, art critics do not pay attention to the extraordinariness of the modern decoration, and actually modern design culture has not been analyzed in the strict sense. If the decoration objects are compared to the products of fashion wearing in terms of person textile product relation, we understand that decoration objects are aimed to be shown as systems that create a decorative effect extending the effect and intensity.

Textiles of high technology product at the present day are products of high performance, high resistance and high efficiency in terms of high functioning textile products. High appearance features, softness, molecular design and ordering control in the textile sciences of the future generation have gained importance. In the 21.century fiber science will cover raw material composition, structure and sensitive molecular arrangement in terms of textile products. People who will live in the future generations will find the textile products we are now using primitive. In the near future textile products of human sciences will be the products with high functioning and environmentally friendly. On the other hand there are natural raw materials. Great natural fiber raw materials are obtained from them. Development of the natural fiber functioning, reforms in the production technology with biotechnology and new and perfect natural fibers will be the textile materials that will be used in the textile products of the future generations.

As the renewals are done by people, the textiles to be obtained will be paid attention to be "human friendly". Things that are needed will not only enable science to develop but also will enable the creative fashion creators to progress. In the 21 . century quality more than quantity will be important for the capitalist textile industry. The industry is to adapt itself to the market.

\section{Ill - The effect of fashion on marketing policies}

Because of the fashion's above mentioned original features, the need of reviewing the marketing policies of the companies participating to the international trade and their marketing tools; and the need of reassessment of the important points in itself reveal itself. In that case, the weight of the first two Ps in the marketing policies classically named as 4 P ( Promotion - Product - Price - Place ) increase much more than others and especially the importance of communication before and after sales that is placed in promotion concept increases. It becomes in evitable that works to develop products for fashion gains a very fast functionality and respond to the fashion demand by product diversification.

\section{Conclusion}

We have examined human and the behaviour of human to others in terms of textile products: and to create various roles for himself/herself and for the other people by creating different feelings on his/her skin, different images since centuries starting from the moment they have realized that clothing like dress and garments they put on themselves make them seem beautiful; to live his/her life in a nice way; to get rid of a monotonous life; to have the chance to try any kind of new clothes, developments of technological clothes at anytime, anywhere and at any status by having a lot of 
clothes and clothes of different styles and thus by having a lot of and different outlooks; as long as people believe that they will have the chance to try they will change their clothes, interior decoration of the places they live even if they do not physically wear out, they wear our visually, psychologically, functionally, technologically, aesthetically and as a result people turn towards the products offered to him/her as new and try them and will continue to try.

This mentioned approach is about daily life. The textile products used in technological and industrial fields do not have to be aesthetically "beautiful". However, its adaptation to the industry branch, sector or natural surface figures it is used is its design aspect and it is important that it carries out the desired function. Humanity has always aimed to progress forward as world, technology and industry. These developments will bring about new developments, new products, new fields and thus, as textile products are used in various and different fields they bring about new textile products, new experiment fields, new materials, new products in parallel with the developments and progress.

Also, as in the present day changing fashion products are easier to access and address to more masses increasing demand categories are formed.

Slow or green textiles which are ecological, nature and human friendly have their places as the current that is increasing and aims to keep the world clean.

As it is people who establish this sector and industry technologies, it is also people who have new experiences with textile products in each field, and who develop products by renewing them in terms of aesthetics and function by uniting the products that are new experienced with new technology and scientific developments and by using new technological and scientific developments in the textile products. Therefore, a textile product requires for a person to live several experiences in terms of psychology, technology, industry, economy, social activity and sports, fashion of the time and communication.

In that respect Textile Design Departments of universities should have important roles. In that field the importance of the cooperation of Industry and University is increasing.

\section{REFERENCES}

ADANIR, Oğuz, Semioloji, Dokuz Eylül Üniversitesi Yüksek Lisans Ders Notlarl, 1991.

ARIKAN, Özden, DAVIS Fred Fashion, Culture, Identity, Press By University Of Chicago 1992, (Moda, Kültür, Kimlik) Yapı Kredi Kültür Sanat Yayıncılık Tic. Ve San. A.Ş. İstanbul, 1997.

BARTHES, Roland, Translated By WARD, Matthew \& HOWARD, Richard, Originally Published in French, System De La Mode, Fashion System Univesity Of California Press Ltd. London, England. 1990.

BOHDANOWITCZ Janet and Clamp Liz, Fashion Marketing Routledge ltd. London-NewYork, 1994.

BOWERS W. John \& COURTRIGHT A. John, Communication Research Methods Scott Foresman and companiy, Cleveland State University Pres. USA, 1984.

BRAZZI, Andrea, The Qestion Of Decoration, Annual Tessuti, Italy, 1992.

COLORS, June-September 2000 Verona / Italy.

CRAIK, Jennifer, The Face of Fashion Cultural Studies in fashion, Routledge ltd., 1995, London and New York. 
CÜCELOĞLU Doğan, İnsan ve davranışı, Psikolojinin temel kavramlarl, Remzi kitapevi Istanbul 1996.

ENCYCLOPEDİA Of Mitology, Octopus Book Ltd., London, 1975.

EVANS, Helen Marie, Man The Designer, Mc Millan Company NewYork, 1973.

FREUD, Sigmund,Totem

ve Tabu,Çev:BERKES, Niyazi, Remzi Kitabevi, Istanbul, 1971.

GOLDMAN, Lucien. Çev: AVŞAR, Timuçin ve AYMUKSA, Füsun. Insan Bilimleri ve Felsefe. Ísbtanbul, Mart, 1977.

GUIROUD, Pierre, Çev: TERIMCE, Mehmet, Gösterge Bilim, M.S. Özel Yayını, Önder Matbaacllı, Sivas, 1977.

HAKKO, Cem. Moda Olgusu, Toplumsal ve Ekonomik Bilimsel Bitirme Tezi, Vakko Yayılarl, Istanbul, 1980.

HALLEN, Bary, Toward A History Of The Carpet, Annual Tessuti, Intemi Annual, Roma, 1992.

HERALD, Jacqueline, Fashions of a Decade, The Seventies, B.T. Batsford Ltd. Hong Kong, 1994.

HÜRRIYET GAZETESİ, 2000, p.14.
INTERNATIONAL TEXTILES INTERIOR, No: 2 September 1990, London.

INTERNATIONAL

TEXTILES,

INTERIOR, Contract Market Retail Report 1987 Trends No: 21986 September. London, V.K.

JARNOW Jeanette \& GUERRIO Miriam, Inside Fashion Business, Toronto, NY, 1991.

LAWER, James, Costume And Fashion C.S. Graphics Singapore, 1995.

LURIE, Alison, The Language Of Clothes, Bloomsburry Publishing Ltd. London, 1992.

MARTINICH Josef S., Production and Operation Management, Printed by John Willey and Sons. inc. New York 1997.

OSKAY, Ünsal, Toplumsal Gelişmede Radyo ve Televizyon (Geri Kalmışlık Açısından Olanaklar ve Sinırlar) Ankara Üniversitesi, Siyasal Bilgiler Fak. Basın ve Yayın Yüksekokulu Yayınları, No: 5 .

OSKAY, Ünsal (metodoloji açısından) Sosyal Bilimlere Giriş (2. Basım) DUVERGER, M. Bilgi Yayınevi Kavaklddere, Ankara, Kasım, 1980.

OSKAY, Ünsal Estetize Edilmiş Yaşam, BENJAMIN, Walter, Dost Kitabevi Yayınları, Yenişehir, Ankara. 
OSKAY, Ünsal. Kitle Haberleșme Teorilerine Giriş. Seçilmiş Parçalar, 2. Baskı, Ankara Üni. Siyasal Bilimler Fakültesi Yayınları, Sevinç Matbaası Ankara, 1973.

READ, Herbert, Sanat ve Endüstri. Çeviren: Dr. Nigar Beyazıt İstanbul Teknik Üniversitesi Matbaasi. Istanbul, 1973.
RONAN Colin, The Universe Explained, Thames and Hudson, Printed and Bounded in Italy, 1994.

WOODHАM M. Jonathan, Twentieth Century Design, Oxford History of art, Oxford University press, 1997, Printed in Hong Kong. 